DOI: $10.18196 / j m h .2017 .0085 .96-104$

\title{
UPICC Sebagai Model Bagi Pembaruan Hukum Kontrak Indonesia dalam Rangka Masyarakat Ekonomi ASEAN
}

\author{
Subianta M andala
}

DATA NASKAH

Masuk: 19 Juni 2015

Diterima: 18 Juni 2016

Terbit: 1 Desember 2017

KORESPONDEN PENULIS:

Kementrian Hukum dan HAM Papua

Jalan Raya Abeputra, Jayapura

Selatan, Vim, Abepura, Kota Jayapura,

Papua 99225

subianta@ hotmail.com

\section{ABSTRAK}

H ukum perjanjian/ kontrak Indonesia merupakan warisan hukum kolonial yang sudah tidak dapat lagi mengakomodasi perkembangan bisnis dan perdagangan internasional yang sangat pesat dewasa ini. Sudah cukup lama Indonesia mewacanakan untuk merevisi KUH Perdata, termasuk hukum perjanjiannya, namun sampai saat ini belum terealisir. M omentum perkembangan di ASEAN, terutama dengan berlakunya M asyarakat Ekonomi ASEAN sejak tahun 2015 mendorong lagi keinginan untuk segera memperbarui hukum kontrak Indonesia. Penelitian ini berusaha untuk menemukan pendekatan yang paling efektif dan realistis untuk dapat mewujudkan cita-cita tersebut. M etode pen elitian yang digunakan adalah yuridis normatif dengan pendekatan futuristik. $\mathrm{H}$ asil penelitian menemukan bahwa UPICC sebagai instrumen internasional yang bersifat soft law dapat dipergunakan sebagai model pembaruan hukum kontrak Indonesia. D engan sifatnya yang soft law ini, memberikan ruang bagi Indonesia untuk memastikan bahwa prinsip-prinsip yang akan diadopsi tersebut tidak bertentangan dengan cita hukum Pancasila.

K ata K unci: H ukum K ontrak, U PICC, ASEAN

\section{ABSTRACT}

The current Indonesian contract law which is inherited from Dutch colonial is no longger compatible with the rapid development of international trade and business practice. Indonesia for quite long time has made an effort to reform its contract law. H owever, those efforts are not successful so far. The entry into force of the ASEAN Economic Community starting from 2015 is a good momentum for Indonesia to revisit the idea of the reform. This research tried to find out the most possible approach for the reform. The research applied normative juridical method with futuristic approach. In conclusion, UPICC as an 
international instrument may well serve as model for the new Indonesian contract law. W ith its soft law character, U PICC may flexibly be adjusted in order not to prejudice the fundamental principles of Pancasila.

Key Words: Contract Law, U PICC,ASEAN .

\section{PENDAHULUAN}

Hukum kontrak Indonesia sekarang ini masih berpedoman pada aturan yang merupakan warisan dari pemerintahan kolonial Hindia Belanda, yaitu Kitab Undang-Undang Hukum Perdata (KUHPerdata) atau Burgerlijk Wetboek (BW) khususnya Buku III tentang Perikatan dan lebih khusus lagi diatur dalam Bab II tentang Perikatan yang Lahir dari Perjanjian. Semula KUHPerdata peninggalan Belanda ini, berdasarkan asas konkordansi, berlaku untuk golongan Eropa di Hindia Belanda. Untuk bangsa Indonesia berlaku Hukum Adat, tetapi orang Indonesia bisa memperlakukan KUHPerdata ini kepada dirinya dengan jalan penundukan terangterangan atau diam-diam. Berdasarkan Aturan Peralihan Undang-Undang Dasar 1945, akhimya KUHPerdata ini berlaku untuk bangsa Indonesia.

Sudah sejak lama Indonesia ingin memiliki hukum kontraknya sendiri mengingat bahwa hukum kontrak Indonesia yang digunakan sekarang, berdasarkan asas konkordansi, adalah Burgerlijk Wetboek (Buku III KUHPerdata) lama, yang berlaku sejak 1838, yang di Belanda sendiri sudah mengalami pembaruan beberapa kali menjadi KUHPerdata Belanda Baru (Niewe Burgerlijk W etboek/ NBW).

Burgerlijk Wetboek lama diadopsi dari Code Civil Perancis dengan beberapa perubahan pada masa abad 19 ketika Eropa dipengaruhi paham liberalisme yang mengagungkan kebebasan individu, sedangkan pada abad 20 (pada saat terjadinya perubahan-perubahan terhadap BW) kepentingan masyarakat luas menjadi semakin menonjol dan perlu diberikan perlindungan, terutama kepada pihak yang lemah.

Selain itu, beberapa ketentuan dalam Burgerlijk Wetboek karena dikutip secara mentah-mentah dari Code Civil Perancis menjadi saling bertentangan satu sama lain. Misalnya ketentuan bahwa jual-beli barang milik orang lain batal karena menurut Code Civil Perancis, pada saat tercapainya kesepakatan barang dan harga maka hak milik berpindah dari penjual kepada pembeli. Ketentuan dalam
BW Belanda yang lama diadopsi dalam Pasal 1471 KUHPerdata. Padahal dalam sistem BW Belanda, perjanjian jualbeli belum memindahkan hak milik tapi hanya melahirkan perikatan antara penjual dan pembeli bahwa penjual wajib untuk menyerahkan barang dan pembeli wajib untuk membayar harga. Penyerahan hak milik terjadi dengan perbuatan hukum yang disebut juridische levering. Dengan demikian, dalam sistem BW dimungkinkan jual-beli dengan sistem indent. M isalnya pembeli memesan mobil dari dealer padahal mobil tersebut masih menjadi milik agen tunggal pemegang merek. Demikian pula ketentuan dalam BW dan Pasal 1460 KUHPerdata, bahwa risiko jual-beli atas barang bergerak yang tertentu ditanggung oleh pembeli, karena dalam Code Civil Perancis perjanjian jual-beli sudah memindahkan hak milik dari penjual kepada pembeli sedangkan dalam BW Belanda, perjanjian jual-beli bersifat konsensual obligatoir artinya meskipun perjanjian sudah sah dan mengikat para pihak tapi belum memindahkan hak milik.

Saat ini, NBW ini sudah jauh lebih maju baik dari segi substansi maupun sistematika sebagai koreksi atas kelemahan-kelemahan yang terdapat dalam BW. Cakupan pengaturannya pun jauh lebih banyak, yang semula terdiri dari 4 buku sudah menjadi 8 buku. Di Indonesia, perbincangan mengenai penggantian KUHPerdata termasuk pembaruan hukum kontrak sudah lama muncul, tidak saja dikalangan akademisi atau universitas, tapi telah menjadi program pemerintah. Berbagai konsep mengenai hukum kontrak/perjanjian/perikatan yang baru pernah dibuat, baik dalam bentuk kajian/penelitian ilmiah maupun naskah akademik atau rancangan undang-undang. Namun, keinginan untuk mewujudkan sebuah hukum perjanjian/kontrak yang baru belum bisa terwujud sampai kini. M omentum untuk menghidupkan kembali gagasan memperbarui atau memodernisasi hukum kontrak Indonesia telah tiba ketika ASEAN mengambil inisiatif untuk melakukan harmonisasi di bidang hukum perdagangan, termasuk hukum kontrak.

\section{RUMUSAN MASALAH}

Berdasarkan latar belakang di atas, beberapa permasalahan yang akan dibahas dalam tulisan ini yaitu langkahlangkah apa yang harus kita lakukan untuk dapat segera mewujudkan suatu hukum perjanjian/kontrak, sampai sejauh 


\section{MEDIA \\ HUKUM}

mana ruang lingkup substansi yang harus diatur dalam undang-undang hukum kontrak ke depan, apakah kita perlu memperhatikan dan mendayagunakan model dari sebuah sistem, asas dan aturan hukum kontrak yang telah diakui kelengkapan dan kualitas substansinya secara internasional, namun yang memang didesain sebagai sebuah kompilasi hukum kontrak perdagangan internasional, khususnya UNIDROIT Principles of International Commercial Contracts (UPICC) dan apakah sumber hukum ini dapat dijadikan acuan dalam membentuk alur dan kerangka berpikir Hukum Perjanjian Nasional Indonesia yang lebih komprehensif dan mampu menjawab banyak persoalan di bidang hukum kontrak yang timbul karena perkembangan kebutuhan masyarakat, baik di tingkat domestik maupun internasional. Tulisan ini mencoba memberikan argumentasi tentang pilihan atau pendekatan yang harus diambil untuk menjawab permasalahan-permasalahan tersebut.

\section{METODE PENELITIAN}

Penelitian ini menggunakan metode penelitian hukum normatif, yaitu jenis penelitian yang mengacu kepada asasasas dan kaidah hukum yang terdapat dalam peraturan perundang-undangan dan putusan pengadilan. Bernard Arif Sidharta mengatakan penelitian hukum normatif adalah jenis penelitian yang lazim dilakukan dalam kegiatan pengembangan ilmu hukum yang di Barat biasa juga disebut dogmatika hukum. Ronald Dworkin menyebutnya sebagai penelitian doktrinal (doctrinal Research), yaitu suatu penelitian yang menganalisis baik hukum yang ada dalam undang-undang maupun hukum yang terdapat dalam putusan pengadilan. Dengan demikian penelitian hukum normatif atau penelitian doktrinal dapat menggunakan dua pendekatan, yaitu pendekatan undang-undang (statute approach) dan pendekatan putusan pengadilan (case approach).

Disamping pendekatan yang telah diuraikan di atas, penelitian ini didukung oleh metode pendekatan antisipatif/ futuristik. Sunaryati Hartono menjelaskan bahwa penelitian hukum futuristik adalah penelitian hukum untuk menemukan jawaban mengenai hukum apa yang seyogianya untuk masa yang akan datang, misalnya penelitian untuk menyusun suatu naskah akademik rancangan undang-undang, atau untuk membuat perencanaan pembangunan hukum. Bertitik tolak dari pengertian tersebut, pendekatan futuristik dalam penelitian ini dimaksudkan untuk mengkaji dan menemukan prinsip-prinsip hukum kontrak internasional yang mutakhir dan memproyeksikan perkembangannya ke depan yang dapat dijadikan referensi bagi pembaruan dan modernisasi hukum kontrak negara-negara ASEAN, khususnya pembaruan hukum kontrak Indonesia.

Penelitian hukum normatif juga sering disebut dengan penelitian hukum kepustakaan. Penelitian kepustakaan dilakukan dalam rangka memperoleh data sekunder, baik yang berupa bahan hukum primer, bahan hukum sekunder, maupun bahan hukum tersier. Bahan hukum primer adalah bahan hukum yang bersifat autoritatif (mempunyai otoritas), dan bahan-bahan hukum yang mengikat, yakni norma dasar atau kaidah dasar seperti undang-undang dan putusan pengadilan. Bahan hukum primer yang digunakan dalam penelitian ini mencakup KUHPerdata, khususnya Buku III. Bahan hukum sekunder adalah bahan yang pada dasarnya memberikan penjelasan bahan hukum primer, misalnya buku-buku hukum atau makalah/paper tentang hukum. Termasuk dalam bahan hukum sekunder yang dipergunakan dalam penelitian ini adalah Unidroit Principles on International Commercial Contracts atau UPICC.

Bahan hukum tersier adalah bahan hukum yang mendukung bahan hukum primer dan bahan hukum sekunder dengan memberikan pemahaman dan pengertian atas bahan hukum lainnya. Bahan hukum tersier yang dipergunakan oleh penulis dalam penelitian ini adalah, diantaranya, Kamus Besar Bahasa Indonesia (KBBI) dan Kamus Hukum (misalnya Black Law Dictionary).

Untuk memperoleh bahan hukum primer dan sekunder penulis melakukan penelitian di beberapa perpustakaan yang ada di Indonesia, diantaranya Perpustakaan Hukum Badan Pembinaan Hukum Nasional di Jakarta, Perpustakaan Mochtar Kusumaatmadja, Fakultas Hukum Universitas Padjadjaran di Bandung, dan Perpustakaan Universitas Indonesia di Jakarta. Selain melalui berbagai perpustakaan yang disebutkan di atas, bahan-bahan hukum juga diperoleh atau diakses melalui internet.

Setelah semua data sekunder terkumpul, langkah selajutnya adalah melakukan analisis terhadap data tersebut. 
Analisis dilakukan dalam rangka memberikan jawaban terhadap permasalahan yang diteliti. Sebelum analisis dilakukan, terlebih dahulu dilakukan pemerikasaan dan evaluasi terhadap semua data yang ada untuk memastikan validitasnya. Penelitian ini bersifat deskriftif analitis dengan pendekatan kualitatif. Oleh karenannya, dalam penelitian ini diuraikan terlebih dahulu permasalahan-permasalahan pokok yang perlu dijawab,dan selanjutnya dilakukan analisis terhadap data sekunder yang ada untuk memperoleh dan menemukan jawaban atas permasalah-permasalahan yang ada. Setelah dilakukan analisis, penulis mengambil kesimpulan yang merupakan jawaban atas permasalahan yang telah diteliti dan diuji secara ilmiah, yaitu ditemukannnya jawaban mengenai pendekatan/cara yang ideal bagi pembaruan hukum kontrak Indonesia.

\section{HASIL PENELITIAN DAN ANALISIS}

\section{A. Menuju H ukum kontrak Indonesia yang Modern}

Gagasan untuk mengganti hukum perjanjian kolonial tersebut dengan hukum perjanjian nasional yang baru sudah lama berkembang. Disamping karena ingin mewujudkan suatu hukum perjanjian nasional bersendikan nilai-nilai dan kepribadian Indonesia, gagasan untuk mengganti hukum perjanjian kolonial tersebut juga disebabkan adanya perkembangan dalam praktek transaksi bisnis dan perdagangan baik dalam skala nasional, regional maupun internasional.

Dalam rangka menghadapi perkembangan praktek bisnis internasional tersebut, peraturan-peraturan hukum perlu secepatnya dimodernisasi, karena saat ini banyak peraturan hukum, khususnya di bidang bisnis dan ekonomi masih terlalu bersifat kuno, reaktif dan insidentil, serta lebih merupakan reaksi sesaat terhadap kebutuhan bisnisjangka pendek yang timbul pada saat-saat tertentu. Salah satu bidang hukum yang perlu segera diperbarui atau dimodemisir adalah hukum perjanjian/hukum kontrak. Hukum perjanjian Indonesia dianggap telah out of date dan tidak dapat lagi mengakomodir perkembangan kebutuhan di dalam bisnis dan perdagangan modern secara memadai.

Sebagaimana telah disinggung di atas, usaha-usaha untuk mengganti, merombak dan memperbarui hukum kontrak Indonesia sudah berlangsung lama. Gagasan Awal untuk melakukan pembaruan hukum kontrak nasional diajukan oleh Wirjono Projodikoro yang menurut beliau hukum perjanjian adalah satu satunya bagian hukum perdata yang segera dapat dilakukan kodifikasi karena bidang hukum tersebut dianggap cukup netral.

Semangat yang mengedepan dalam diri Wirjono Projodikoro adalah menghidupkan lembaga perjanjian dalam Hukum Adat. Hukum Adat pada hakikatnya hukum yang berbeda di berbagai daerah. Namun demikian, perbedaan yang ada dalam Hukum Adat ini, khususnya Hukum Perjanjian, tidak begitu tajam bila dibandingkan dengan Hukum Waris atau Perkawinan yang sarat akan nilai-nilai. Wirjono Projodikoro secara tegas menyatakan sebagai berikut:

"Lain halnya dengan Hukum Perjanjian, yang ternyata tidak memperlihatkan begitu banyak perbedaan yang mendalam di antara hukum yang berlaku bagi pelbagai golongan dan daerah di Indonesia. M aka dari itu, saya berkeyakinan, bahwa dengan sekuat tenaga dan kemauan yang baik dapat diusahakan agar dalam jangka pendek diketemukan suatu perumusan H ukum Perjanjian di Indonesia, yang dapat ditetapkan berlaku bagi segenap warga negara Indonesia. U ntuk permulaan, dapat dimulai dengan bagian umum dari H ukum Perjanjian itu".

Pada tahun 1974 pernah disusun sebuah Rancangan Undang-Undang (RUU) Hukum Perikatan yang diketui oleh R. Soebekti. Sistematika RUU ini mengikuti sistimatika Buku III KUHPerdata. ${ }^{1}$ Tercatat pula pada tahun 1992 BPHN pernah membentuk Tim Kerja Penyusunan Naskah Akademis Peraturan Perundang-undangan tentang Kontrak di Bidang Perdagangan yang diketuai oleh Sunaryati Hartono. ${ }^{2}$ Dalam Naskah Akademik tersebut dibahas mengenai asas-asas hukum kontrak, kontrak baku, kontrak pemerintah, dan kontrak internasional.

Upaya pembaruan hukum kontrak terakhir pernah dilakukan oleh R. Setiawan melalui penyusunan Naskah Akademik Peraturan Perundang-undangan tentang Perikatan pada tahun $1994 .{ }^{3}$ R. Setiawan berpendapat bahwa sebagian ketentuan Hukum Perikatan dalam KUHPerdata sudah tidak sesuai lagi dengan perkembangan yang ada, dan sebagian yang lain masih relevan untuk dipertahankan. Seiring dengan 


\section{MEDIA HUKUM}

era globalisasi yang menyentuh hampir semua aspek kehidupan masyarakat Indonesia, R. Setiawan secara tegas menyatakan bahwa bidang hukum, khususnya Hukum Perjanjian, mulai terkena pengaruh apa yang dikenal sebagai Convention Law dan Community Law. Lebih lanjut, R. Setiawan menyatakan bahwa Hukum Perikatan dalam konteks internasional dihadapkan pada masalah yang berkaitan dengan harmonisasi hukum.

Ketiga naskah akademik RUU tersebut di atas yang dimaksudkan sebagai upaya pembaruan hukum nasional di bidang Hukum Kontrak tampaknya masih terfokus pada pengaturan terhadap transaksi-transaksi yang bersifat domestik. Sekalipun perkembangan-perkembangan internasional turut juga mempengaruhi perancang dalam menyusun naskah RUU tersebut, sebagaimana R. Setiawan, tetapi rumusan naskahnya masih bermuara pada kepentingan-kepentingan domestik. Eksistensi kontrakkontrak internasional dalam lalu-lintas perdagangan belum mendapat sentuhan yang berarti secara konseptual. Upaya menghidupkan kembali gagasan pembaruan hukum kontrak Indonesia timbul belakangan ini terkait dengan perkembangan yang terjadi pada organisasi ASEAN yaitu keinginan untuk mewujudkan suatu masyarakat ASEAN yang lebih terintegrasi secara ekonomi pada tahun 2015. Dalam kaitan itulah kemudian sejak2012, Badan Pembinaan Hukum Nasional (BPHN) menempatkan pembaruan hukum kontrak Indonesia merupakan salah satu agenda prioritas. Beberapa kegiatan terkait dengan pembaruan hukum kontrak telah dilaksanakan dalam dua tahun terakhir ini. Masukan dan rekomendasi mengenai perlunya segera dibuat Undangundang Hukum Kontrak telah mendorong BPHN untuk secara serius menyusun sebuah naskah akademik. Selain itu secara simultan, BPHN juga menyusun sebuah Naskah Akademik Rancangan Undang-Undang Pengesahan Konvensi PBB mengenai Jual Beli Barang International (CISG) dalam upaya mempersiapkan kemungkinan Indonesia meratifikasi Konvensi CISG tersebut.

Dijelaskan dalam Naskah Akademik Hukum Kontrak 2013 mengenai alasan perlunya pembaruan hukum kontrak, yaitu diantaranya bahwa hukum perjanjian yang diatur dalam Buku III, Bagian II KUHPerdata, sebagai sumber hukum utama Hukum perjanjian Indonesia, telah out of date dan dianggap tidak dapat lagi mengakomodir perkembangan kebutuhan di dalam bisnis dan perdagangan modern secara memadai.

Berbeda dengan materi muatan yang diatur dalam naskah akademik yang pernah ada sebelumnya yang mencakup semua jenis perikatan, maka Naskah Akademik 2013 ini mempunyai ruang lingkup yang lebih sempit, yaitu hanya akan mengatur atau merubah ketentuan mengenai perjanjian (Bab 2 dari Buku III Perikatan yang timbul dari Kontrak atau Perjanjian). Alasan mengapa ruang lingkup perubahan hanya mengenai perjanjian saja didasarkan pada pertimbangan praktis, yaitu semata-mata karena keterbatasan waktu menjelang pembentukan ASEAN Economic Community pada tahun 2015. Jadi pembentukan ASEAN Economic Community 2015 menjadi "pendorong dan sekaligus merupakan time constraint dalam upaya pembaruan bidang hukum Perikatan itu secara menyeluruh". Sehingga dengan demikian fokus diarahkan pada Buku III Bagian 2 KUHPerdata tentang Perikatan yang Bersumber pada Perjanjian. Naskah akademik tersebut memberikan rekomendasi agar dalam jangka pendek perubahan dan atau penyempurnaan perlu diawali dengan asas-asas dan aturan hukum umum hukum kontrak. Setelah itu, untuk jangka panjang barulah dilaksanakan perubahan atau penyempurnaan terhadap perjanjian-perjanjian tertentu yang terdapat dalam Bab V sampai dengan Bab XVII Buku III KUHPerdata. ${ }^{4}$

Prinsip-prinsip yang melandasi arah pengaturan perubahan hukum kontrak Indonesia ke depan, sebagaimana disebutkan dalam Naskah Akademik Hukum Kontrak Indonesia 2013, dapat diuraikan berikut ini. ${ }^{5}$ Hukum Kontrak Indonesia harus diturunkan dari nilai-nilai Pancasila dan Pembukaan serta pasal-pasal yang relevan dari Undangundang Dasar 1945. Keduanya harus menjadi landas-pijak UU Hukum Perjanjian Nasional. Dengan kata lain, pemikiranpemikiran yang terbit dari falsafah hidup bangsa Indonesia serta landasan konstitusional Negara Kesatuan Republik Indonesia harus menjadi politik hukum perjanjian nasional; dan politik hukum inilah yang sejauh mungkin menjiwai substansi UU Hukum Perjanjian Nasional.

Hukum kontrak Indonesia ke depan harus didesain sebagai sub-kodifikasi dari kodifikasi Hukum Perikatan Nasional yang akan datang, sehingga penyusunan UU Hukum Perjanjian Nasional harus disusun dengan 
mengantisipasi asas-asas umum Hukum Perikatan Indonesia yang baru.

Selanjutnya, hukum kontrak Indonesia didesain sebagai peletak dasar Hukum Perjanjian di Indonesia, tanpa harus menetapkan orientasi khusus terhadap civil law, common law, hukum Islam atau hukum adat, atau tradisi hukum lainnya. UU Hukum Perjanjian Nasional harus dikembangkan sebagai Hukum Perjanjian yang khas Indonesia, karena sejalan dengan asas-asas filsafati Pancasila, namun harus dapat menjawab persoalan-persoalan hukum perjanjian modern baik di tingkat nasional maupun internasional.

Prinsip lainnya yang hendak dibangun dalam hukum kontrak Indonesia kelak adalah memuat pula asas-asas umum Hukum Perjanjian yang sesuai dengan asas-asas yang dikenal di berbagai sistem hukum di dunia, namun dengan substansi yang diwarnai oleh pemikiran-pemikiran filsafati Pancasila, yang lebih banyak memajukan kepentingan bersama dan kepentingan masyarakat daripada kepentingan orang-perorangan.

\section{B. U PICC sebagai Model bagi Pembaruan Hukum Kontrak Indonesia}

Terdapat setidaknya 3 faktor lingkungan yang mempengaruhi pembangunan sistem hukum nasional, yaitu (1) faktor intern nasional, (2) faktor regional, (3) faktor global. Faktor internal nasional meliputi hakikat dari sistem hukum nasional, adanya pluralisme hukum, perubahan masyarakat, hubungan internasional yang semakin terbuka. Faktor lingkungan global merujuk pada keikutsertaan Indonesia dalam Perjanjian Pembentukan Organisasi Perdagangan Dunia (WTO) yang setiap negara anggotanya wajib untuk menyesuaikan kebijakan dan hukum perdagangannya agar sesuai dengan kesepakatan-kesepakatan yang telah dihasilkan oleh WTO.

Pengaruh lingkungan regional terhadap pembangunan hukum nasional tentu saja pada dewasa ini akan banyak berasal dari perkembangan di ASEAN, khususnya dalam kaitan dengan pembentukan Masyarakat Ekonomi ASEAN yang dimulai pada tahun 2015. Perkembangan ini jelas membutuhkan kesiapan untuk menghadapi persaingan yang cenderung semakin ketat, sehingga diperlukan berbagai upaya untuk meningkatkan efisiensi termasuk perbaikan sistem dan pranata hukum yang mampu mendukung kegiatan ekonomi dan bisnis yang semakin modern. Segala perubahan dengan berbagai implikasinya tersebut semestinya terus dipantau dengan sikap terbuka, agar dapat dicari jalan untuk lebih menyesuaikan diri dengan perubahan-perubahan itu tanpa merugikan kepentingan nasional.

Menurut Munir Fuady beberapa hal yang harus diperhatikan dalam merevisi hukum kontrak versi KUHPerdata Indonesia, yaitu (1) penyesuaian dengan perkembangan teknologi, bisnis dan kehidupan di zaman modern ini, (2) penyesuaian dengan perasaan dan kesadaran hukum yang hidup dalam masyarakat Indonesia, (3) penyesuaian dengan filosofi Pancasila, (4) penyesuaian dengan sistem hukum lain seperti anglo saxon yang cukup mempengaruhi hukum kontrak secara universal (5) penyesuaiannya dengan perkembangan hukum kontrak secara internasional sebagaimana tercermin dalam berbagai konvensi Internasional yang berkaitan dengan hukum kontrak.

Pada saat ini hanya ada dua instrumen internasional yang berperan besar bagi pengembangan hukum kontrak, khususnya kontrak internasional, yaitu Konvensi Perserikatan Bangsa-bangsa tentang Kontrak-kontrak Jual Beli Barang Internasional atau The United Nations Convention on Contractsfor the International Sale of Goods ("CISG") dan UPICC. Kedua instrumen hukum internasional tersebut mempunyai keterkaitan, saling melengkapi, dan lahir dengan latar belakang, tujuan dan maksud yang kurang lebih sama. Dibandingkan dengan CISG, UPICC mempunyai kelebihan. Selain sifatnya yang fleksibel, UPICC memberikan aturan hukum kontrak yang bersifat umum (general principles of contract law) dan tidak terbatas pada jual beli. UPICC memuat asas dan aturan yang "lebih baik" berdasarkan standar praksis internasional. UPICC sekaligus merupakan kompilasi yang tidak tertutup dan selalu terbuka untuk dikembangkan dan dilengkapi sesuai perkembangan kebutuhan di dalam kegiatan bisnis dan perdagangan internasional. Kenyataan inilah yang menumbuhkan pandangan bahwa UPICC adalah hasil dari upaya "merumuskan kembali" (restatement) asas dan aturan hukum kontrak, yang lebih dari sekadar menegaskan kembali 


\section{MEDIA
HUKUM}

apa yang sudah dikenal dalam hukum kontrakinternasional, tetapi juga memuat asas dan aturan yang inovatif yang umumnya tidak dikenal di dalam sistem hukum kontrak nasional/domestik, seperti prinsip fair dealing, penghalusan terhadap ketidakadilan (policing against unfairness), hardship, gross disparity dan favour contractus.

Tujuan diperkenalkannya UPICC adalah untuk memberikan jalan keluar alternatif atas kesulitan-kesulitan yang dihadapi dalam praktik perdagangan internasional sebagai akibat kurang memadainya aturan hukum mengenai kontrak dagang internasional. Dengan demikian, instrumen ini dimaksudkan untuk memberikan solusi yang dapat diterima pada level internasional, maka aturan yang diadopsi atau yang dipilih adalah yang paling sesuai dengan kebutuhan khusus perdagangan internasional, meskipun mungkin aturan tersebut merepresentasikan pandangan minoritas di tingkat hukum domestik. ${ }^{6}$ Inilah sebabnya mengapa kemudian UPICC memperoleh reputasi sebagai sumber utama yang mencerminkan aturan hukum yang "lebih baik" (better law) untuk kontrak-kontrak internasional. Sebagai contoh, dalam konteks internasional, "harapan-harapan para pihak yang sah" (legitimate expectations of the parties) dianggap terpenuhi apabila solusi yang diperoleh dari penerapan hukum nasional dan yang memenuhi harapan para pihak ternyata juga dapat diterima secara internasional. UPICC dianggap mampu memberikan status internasional atas solusi-solusi nasional.

Selain kegunaan UPICC yang disebutkan di atas, hal yang paling penting dalam konteks penulisan ini adalah UPICC dapat menjadi model bagi para legislator nasional dan internasional. Ini berarti bahwa UPICC dapat digunakan sebagai model pembaruan hukum nasional suatu negara dan hukum internasional di bidang kontrak dagang. Pada tingkat nasional UPICC dapat berfungsi bagi negara-negara berkembang yang belum mengatur mengenai asas-asas hukum kontrak atau negara-negara yang berniat untuk menyesuaikan hukum kontraknya dengan adanya unsur asing pada standar internasional yang berlaku dalam bidang transaksi ekonomi. Bahkan pada situasi tertentu suatu negara yang telah mempunyai sistem hukum tertentu setelah mengalami perubahan struktur yang mendasar di bidang sosial dan ekonominya mempunyai kepentingan untuk meninjau kembali sistem hukum yang berlaku terutama di bidang ekonomi dan aktivitas perdagangan (internasional). Secara khusus tentu saja UPICC ini sangat bermanfaat bagi negara negara yang hukum kontraknya sudah jauh ketinggalan zaman dan ingin melakukan perubahan atau memodernisir hukum kontrak nasionalnya.

Dari uraian di atas, dapat ditarik sebuah kesimpulan bahwa UPICC secara prinsip akan dapat diterima sebagai sumber rujukan atau referensi bagi pembaruan dan modernisasi hukum kontrak Indonesia, dengan beberapa alasan yang diuraikan secara singkat berikut ini:

1. UPICC dirancang dengan tujuan, salah satunya, untuk dijadikan model bagi pembaruan hukum kontrak suatu negara;

2. UPICC dianggap sebagai prinsip-prinsip hukum kontrak modern yang merepresentasikan perkembangan hukum kontrak internasional baik yang bersumber dari sistem civil law maupun common law;

3. UPICC sebagai sebuah soft law dapat dijadikan referensi dengan penyesuaian-penyesuaian seperlunya berdasarkan kebutuhan dan kondisi suatu negara;

4. Berkaitan dengan poin 3, terdapat ruang untuk memastikan bahwa nilai-nilai Pancasila (dan hukum adat yang masih relevan) tetap menjadi pegangan dalam penyusunan hukum kontrak Indonesia, walaupun faktor eksternal (kebutuhan dan perkembangan internasional, khususnya dalam konteks mewujudkan modernisasi dan harmonisasi hukum kontrak di ASEAN) perlu juga dipertimbangkan.

5. UPICC memuat prinsip-prinsip yang sebagian besar sudah dikenal dalam sistem civil law. Masyarakat Indonesia sebenarnya sudah terbiasa dengan prinsip-prinsip hukum kontrak barat (civil law). Sekalipun KUHPerdata semula diberlakukan untuk golongan Eropa di Hindia Belanda, namun orang Indonesia bisa memberlakukan KUHPerdata ini kepada dirinya dengan jalan penundukan terangterangan atau diam-diam. Berdasarkan Aturan Peralihan Undang-Undang Dasar 1945, akhirnya KUHPerdata ini berlaku untuk bangsa Indonesia. 


\section{KESIM PULAN DAN SARAN}

\section{A. Kesimpulan}

1. Sudah saatnya Indonesia segera melakukan pembaruan hukum perjanjian/kontraknya untuk menyesuaikan dengan perkembangan transaksi bisnis global.

2. Secara realistis untuk saat ini, fokus pembaruan hukum kontrak Indonesia hanya dalam tataran prinsip-prinsip hukum (kontrak) saja dengan merujuk pada prinsipprinsip hukum kontrak yang secara universal telah diterima dalam praktik.

3. UPICC adalah instrumen yang paling fleksibel untuk dijadikan model atau referensi bagi pembaruan hukum kontrak Indonesia karena sifatnya yang soft law, sehingga memberikan ruang yang cukup bagi Ind onesia untuk memastikan bahwa adopsi terhadap prinsip-prinsip umum UPICC tetap dalam bingkai cita hukum Pancasila.

\section{B. Saran}

1. Pemerintah Indonesia sebaiknya segera memasukan pembaruan hukum kontrak Indonesia sebagai salah satu prioritas untuk dimasukan dalam program legislasi Nasional (Prolegnas).

2. Pembaruan hukum kontrak Indonesia harus juga memperhatikan perkembangan hukum kontrak di kawasan ASEAN dalam rangka ikut mewujudkan kerangka hukum ASEAN yang harmonis sehingga dapat berkontribusi bagi perkembangan Masyarakat Ekonomi ASEAN yang sudah mulai berlaku sejak 2015.

\section{DAFTAR PUSTAKA}

Bambang Sunggono, M etodologi Penelitian Hukum, C etakan kedua, Jakarta: RajaG rafindo Persada, 1998. H ijma, Jaap dan $\mathrm{H}$ enk Snijder, The N etherland $\mathrm{N}$ ew Civil C ode, Jakarta: National Legal Reform Project, 2010. $\mathrm{H}$ uala A dolf, Instrumen-Instrumen $\mathrm{H}$ ukum tentang $\mathrm{K}$ ontrak Internasional, Bandung: CV Keni Media, 2011.

Johnny Ibrahim, Teori dan M etodologi Penelitian Hukum N ormatif, Malang: Bayumedia Publishing, 2011.

Moh. Hasan Wargakusumah, (Ketua Tim), Laporan

A khir Tim Perumusan Harmonisasi H ukum tentang M etodologi H armonisasi H ukum, Jakarta: BPH N , 1997. Ronny $\mathrm{H}$ anitijo Soemitro, M etodologi Penelitian H ukum dan Jurumetri, Jakatrta: G halia Indonesia, 1990.

Soerjono Soekanto dan Sri Mamudji, Penelitian H ukum N ormatif Suatu Tinjauan Singkat, Jakarta: RajaGrafindo Persada, 2003.

Sulistyowati Irianto dan Shidarta (Editor), M etode Penelitian Hukum Konstelasi dan Refleksi, Jakarta: Yayasan O bor Indonesia, 2009.

Sunaryati Hartono, Penelitian H ukum di Indonesian pada A khir A bad ke-20, Bandung: Alumni, 2006.

Taufiqurrahman, Karakter Pilihan $\mathrm{H}$ ukum, Kajian tentang L ingkup Penerapan the $U$ nited $\mathrm{N}$ ations $\mathrm{C}$ onvention on C ontracts for the Interntional Sale of G oods (SISG ) 1980, Surabaya: Bayumedia Publishing, 2010.

Warendorf, $\mathrm{H}$ ans $\mathrm{CS}$, The $\mathrm{C}$ ivil $\mathrm{C}$ ode of the $\mathrm{N}$ etherlands, The N etherlands: Kluwer Law International,2009. W irjono Prodjodikuro, A sas-A sas H ukum Perjanjian, Bandung: Mandar Madju, 2000.

Naskah A kademik

Naskah A kademik Peraturtan Perundang-undangan tentang hukum Perikatan, BPH N, D epartemen Kehakiman RI, 1976/ 1977.

N askah Akademik Rancangan U ndang-U ndang H ukum Kontrak, Jakarta:BPH N, 2013.

Naskah Akademik Rancangan U ndang-U ndang Pengesahan Konvensi PBB mengenai Jual Beli Barang International (CISG), Jakarta:BPH N, 2013.

$\mathrm{N}$ askah A kademik tentang Kontrak di Bidang Perdagangan, BPH N D epartemen Kehakiman, 1994.

Jurnal/ Makalah

Derains, Yves, "The Role of U NIDROIT Principles in International Commercial Arbitration (1): A European Perspective", Bulletin International C ourt of A rbitration, U N IDR O IT Principles of International C ommercial C ontracts - R eflections on Their U se in International A rbitration, Special Supplement, ICC, Publishing S.A, 2002.

Dworkin, Ronald dalam Bismar N asution, "M otode Penelitian Hukum Normatif dan Perbandingan Hukum", M akalah, disampaikan pada Dialog Interaktif tentang Penelitian Hukum dan Hasil Penulisan H ukum pada M ajalah A kreditasi, Fakultas Hukum USU, 18 Februari 2003. 
Michael Joachim Bonell, "Towards a Legislative Codification of the UNIDROIT Principles", (2007), 12 (2) U nif.Law Rev, 2007.

M unir Fuady, "Prinsip-Prinsip H ukum Perjanjian dalam KU H Perdata Indonesia", Makalah disampaikan dalam sebuah Seminar Nasional "Pembaruan H ukum K ontrak Indonesia yang diselenggarakan oleh Badan Pembinaan Hukum Nasional, Jakarta, 28 A gustus 2013. 